\title{
The Relationship between Residential Property Development and Property Tax generation in Ibadan North, Oyo State
}

\author{
Ajayi M. T. A. ${ }^{1}$, Ogunbajo A. Rukaiyat ${ }^{1}$, Sule I. Abass $^{1} \&$ Abdulkareem Sekinat ${ }^{1}$ \\ ${ }^{1}$ Department of Estate Management and Valuation, School of Environmental Technology, Federal University of \\ Technology, Minna, Nigeria \\ Correspondence: Ogunbajo A. Rukaiyat, Department of Estate Management and Valuation, School of \\ Environmental Technology, Federal University of Technology, Minna, Nigeria. Tel: 234-80-6626-9465. E-mail: \\ rukky.adeola@futminna.edu.ng
}

Received: March 4, 2014 Accepted: April 28, 2014 Online Published: July 31, 2014

doi:10.5539/jsd.v7n4p206

URL: http://dx.doi.org/10.5539/jsd.v7n4p206

\begin{abstract}
This paper examined the relationship between residential property development and property tax generation in Ibadan North Local Government, Oyo State- Nigeria. Data on residential properties within the Local Government for an eleven year period (1999 - 2010) was obtained from the appropriate planning authority, while records of property taxes generated within the same eleven year period was sourced from the taxing authority within the local government. Regression analysis was used to examine the degree and nature of relationship that a change in the number of residential properties will have on the generation of property taxes. Results showed that the actual property tax paid in Ibadan North Local Government Council is being influenced by the number of residential buildings within the council at about $59.3 \%$ variation. This implies that a positive variation in the number of residential buildings within the council will lead to a positive variation in the actual property tax generated. Investigation further revealed that this revenue option is however not fully utilized as payments of these taxes are not fully enforced by the taxing authority. It is therefore paramount that the local government seeks for means of improving its tax base through effective property taxation, thus increasing funds available for community development projects such as electrification, road construction, drainages and other essential utilities.
\end{abstract}

Keywords: property tax, residential property, property development, improvement

\section{Introduction}

Real estate development can be regarded as the most significant aspect of national development as it forms the physical structure of a nation on which the standard of a nation's development is based. In one way or another, land provides the shelter, privacy, and services that are essential in sustaining modern life, thus the basic need to occupy land has led all organized societies to control the use of land and property either by taxation or legislation (Olusegun, 2003). In actual fact, wealth cannot be generated without reference to land and buildings. It is therefore relevant and rational that this source of wealth be taxed for social and economic reasons in order to raise revenue for the government who takes care of the physical environment of landed properties and also create the enabling environment for the citizens to create wealth (Ismail, 1986). As observed by Tsoodle and Turner (2008), Property taxes are a fundamental source of wealth for Local Governments in the United States, and they make up to $73 \%$ of Local Government tax revenue. Similarly, almost all local governments worldwide rely to some extent on property taxes to pay for local services (Slack, 2010). As observed by England, Zhao and Huang (2013), a substantial portion of property taxes in the United States were levied on residential property owners, and these property owners in turn benefited from the municipal services that those property taxes helped to finance.

The fact that the total supply of land in a country is fixed, and the view that the income derived from the ownership of land is a kind of "unearned" surplus, continues to lend support for measures to tax economic rent. Conceptually, land as a factor of production and a source of wealth should be subject to taxation. According to Ogbuefi (2004), the suitability of land as a source of taxable revenue however depends on physical economic, legal, political, and socio-cultural factors.

Many countries have introduced a development tax which is levied on any increase in the market value of land. 
Much of the increased value of land arises from the efforts and expenditures of the community as a whole. Public expenditures on infrastructure such as that on roads, water, gas and electricity services will dramatically increase the values of land which is adjacent to such services. Taxation is therefore an important factor in economic planning and development and also an agent of social change.

However, the under-utilization of property tax as a means of generating revenue for local councils in parts of Nigeria and Ibadan North local government leads one to ask whether the tax is actually a good tax for local government, and if it is, why is it not well utilized, ie, by fully enforcing the payments of these taxes by the taxing authority. Also, what are the ways to increase property tax revenues to ensure improved funding of essential utilities at the local level such as access roads, schools, health care centres, electricity and drainages? This paper explores the relationship between residential property development and Property tax generation in Ibadan North Local government, Nigeria. It clearly examines the effect of increased property development on property taxes accruing to local authorities and vice versa.

\section{Justification of the Study}

Ibadan North is one of the Local Government Areas in Oyo state where property taxes is being paid by residents and documented by the relevant authorities. Monies generated from this form of taxation accounts for a part of revenues generated by the Local government to provide essential utilities for the residents. It is well known however, that an important indicator of how much is charged as property tax and acceptable to the payee is the level of infrastructural development in the area since it will justify the readiness of people to pay. In this regard, Ibadan North has been described by many as the commercial nub of the city, as the area accommodates a large number of commercial activities including the ultra-modern market, banks and other financial institutions, educational facilities, administrative buildings and residential buildings. The area can be described as having a fairly high level of infrastructural development. However, the redevelopment and reclaimation of parts of Ibadan North as well as the need to adequately maintain and upgrade existing utilities and amenities justifies the need for adequate financial resources which can be achieved through effective property taxation. While certain projects such as the dualization of some roads in the area have been identified, other such community development projects are being proposed by the council. This study is justified by the need to explore property taxation as a means to generate significant revenues to fund community projects at the local level.

\section{Property Tax and Residential Property Development}

In developed nations of the world, property taxes are used to finance very visible services and other essential utilities. Individuals promoting urban revitalization hold that benefits from developments do not accrue solely to developers and landlords, instead they also improve values of surrounding properties and neighbourhoods, while also increasing the tax base for municipal governments (Newel, 2009). Bird (2001) argued that property tax is a good tax for local government because it is fair, difficult to evade, and promotes local autonomy and accountability. According to Slack (2010), almost all local governments worldwide rely to some extent on property tax to pay for local services

Bird and Slack (2002) in their study on land and property taxation provided an insight into the importance of generation of property taxes within a locality. It was stressed that property tax is appropriate as a local revenue source because real property is immovable and domiciled within a community, thus it is unable to shift location in response to the tax. The study also revealed that property tax is considered as an appropriate source of revenue for local government as there is the connection between many of the services typically funded at the local level and the benefit to property values. The study concluded that property tax is a benefit tax to the extent that public services provided to the property owner enhance the value of the property and result in higher property taxes. Thus where the matching does not occur, there will be a pattern of positive and negative subsides which will influence the residential development patterns.

Yenger (2005) asserted that house values (property values) depend on local public service quality and on local property rates - a phenomenon known as capitalization. However, while Yenger (2005) provided the theoretical framework for a model that expresses the relationship between property tax and residential property development; Song and Yuez (2008) in examining how differences in property within cities affect urban sprawl, established through a rigorous mathematical model that there is a relationship between property tax and change in improvement on land via the ability of residents to pay for what they can afford. England and Ravichandran (2010) showed through numerical simulations that a higher property tax rate will favour construction of houses with fewer storeys and with more compact footprints.

On the contrary, Zodrow (2001) sees property tax as a tax on capital that results in distortions in the housing market and in local fiscal decisions. Property tax based on the value of land and building was seen to discourage 
development and results in the under-utilization of land, thus the amount of capital per unit of land is less than what is economically efficient. In the same vein, Lewyn (2013) argued that if a residential development is unusually affordable, it will produce less property tax revenue than the rest of the housing stock. This implies that the residential property will reduce the municipal tax base, which means higher taxes or fewer services for existing tax payers. Using descriptions of over 36000 houses in New Hampshire between 1985 and 2006, England, Zhao and Huang (2013), submitted that property taxes have impacted more negatively on lot size than building size. They further stressed that the significant effect of property taxation on the decision of residential property development provide some evidence that the property taxation is not merely a user fee and that it does affect allocation of residential capital across municipalities.

While the effects of increased property development on property taxes accruing to local authorities can be identified, the true relationship and interconnection between these and the benefits to government and society has not been adequately addressed. Although, this have often been alluded to but not well documented.

\section{Incidence of Taxation}

\subsection{Direct Incidence}

Taxes here are paid directly. Residential property owners, commercial property owners and farm owners pay property taxes directly. They can often however pass those taxes onto others, so they may not ultimately bear the cost.

\subsection{Indirect Incidence}

Ultimately these are taxes that are borne by labor or capital (natural or produced). Capital originates through labour or through capital gain as natural resources becomes scarce. It can be passed on through inherited wealth. The tax on labour is in this case most easily thought of as a tax on consumption that makes working to earn income less attractive. A property income is partly a tax on the consumption of services from property. However, Bird and Black (2003) postulates the following views, that:

(i) Those who view taxes in residential real property as essentially taxes on housing services tend to think that property taxes are inherently, since as a rule, housing constitutes a relatively larger share of consumption for poorer people.

(ii) Those who view property taxes as essentially a tax on capital tend to think that such are inherently progressive, since as a rule, income from capital constitutes a relatively higher share of income for richer people.

(iii) Those who view the portion of the tax that falls on land as being paid not of economic rent consider it to be inherently equitable to tax such unearned increments arising (often) from public actions.

(iv) Those who view property taxes as essentially benefit taxes tend to think that there is no more sense in asking if the 'price' of local public services does not raise any question of incidence.

\section{Data and Research Methodology}

Data for this study were obtained from up to date records from the appropriate planning authority and the taxing authority within the selected local government. Data received from these two authorities include records of the number of residential properties within the local government over an eleven (11) year period between 1999 and 2010, as well as Records of property taxes generated within the same eleven year period $(1999-2010)$ respectively. Regression analysis was adopted to identify the relationship between the change in number of Residential properties and Property tax generated within the study area. This is to examine the degree and nature of relationship that a change in the number of residential properties will have on the generation of property tax. It will also examine the need for local government to either seek for a means of retaining tax base or improve it (that is to discourage as much as possible change in use for various purposes like zoning, exemption and relief as the case may be).

Thus the element of the linear regression is given as

$$
y=a+b 1 x 1+b 2 \times 2+b 3 \times 3
$$

Where $y$ is the dependent variable

And $\quad \mathrm{x}$ is the independent variable

Thus, in the first instance when relationship is between the changes in the number of residential properties and the generation of property tax, the dependent variable $y$ is the amount of tax generated in the local government over a period of eleven years while the independent variable $\mathrm{x}$ is the number of residential properties in the area over the eleven years under study. 


\section{Results}

Table 1. The Regression analysis between the actual property tax generated on $\mathrm{Y}$ axis (Apt N) and the number of the residential building in Ibadan north local government

\begin{tabular}{|c|c|c|c|c|c|c|c|c|}
\hline Yaxis & X axis & Model & Equation & $R^{2}$ & Fcal & Ftab & Sig & Rmks \\
\hline & & & & & & & Level & \\
\hline $\mathrm{Apt}_{\mathrm{NE}}$ (Actual Property & BldP $_{\mathrm{NE}}($ Population of & Linear & $\mathrm{Apt}_{\mathrm{NE}}=50.7 \mathrm{BldP} \mathrm{P}_{\mathrm{NE}}$ & 59.3 & 13.140 & & .006 & $\mathrm{~S}$ \\
\hline tax Paid In Ibadan & Residential Building In & & 210908 & & & & & \\
\hline \multirow[t]{8}{*}{ North LG } & Ibadan North LG) & & & & & & & \\
\hline & & $\log$ & $\mathrm{Apt}_{\mathrm{NE}}=$ & 58.0 & 12.419 & & .006 & $\mathrm{~S}$ \\
\hline & & & Log $\quad .1535366 \mathrm{BldP}_{\mathrm{NE}} \quad-$ & & & & & \\
\hline & & & $1 \mathrm{E}+007$ & & & & & \\
\hline & & Quadratic & $\mathrm{Apt}_{\mathrm{NE}}=.002 \mathrm{BldP}_{\mathrm{NE}}^{2}$ & 60.9 & 6.229 & & .023 & $\mathrm{~S}$ \\
\hline & & & $-49.11 \mathrm{BldP}_{\mathrm{NE}}+1279637$ & & & & & \\
\hline & & Cubic & $\mathrm{Apt}_{\mathrm{NE}}=2.78 \mathrm{E}-008 \mathrm{BldP}_{\mathrm{NE}}^{3}$ & 61.6 & 6.427 & & .022 & $\mathrm{~S}$ \\
\hline & & & $-.001 \mathrm{BldP}_{\mathrm{NE}}^{2}+958056.8$ & & & & & \\
\hline
\end{tabular}

The result from table 1 shows that actual property tax paid in Ibadan North local government council is being influenced by the population of the residential buildings within the council at about $59.3 \%$ variation. The $\mathrm{F}$ calculated of 13.14 is less that $\mathrm{F}$ tabulated while the significant level of 0.006 is less than 0.05 . The implication here is that $\mathrm{H}_{1}$ is accepted. The Model equation however indicates that a positive variation in the number of the residential buildings within the council will lead to a positive variation in the actual property tax paid.

\section{Conclusion}

The residential property tax is a good tax for local governments, yet it is not a major source of revenue for local governments in many developing countries. The services and amenities enjoyed by residential property owners and occupiers are usually provided by the Government, thus it is paramount that residential property owners are properly taxed by the government to generate revenue to effectively finance facilities and utilities, and also manage and maintain existing ones within the locality. How well property taxes are administered not only impacts on how much revenue is collected, but also affects the equity and efficiency of the tax. Having carefully examined the relationship between residential property development and property tax generation in Ibadan North Local Government Council, issues raised herein indicates that a positive variation in the number of residential buildings will lead to a positive variation in the actual property tax paid. Thus, an improvement in residential property development is of great significance if the tax base of the local government council is to be improved.

\section{References}

Bird, R. M. (2001). Subnational Revenues: Realities and Prospects. Washington Dc: World Bank Institute.

Bird, R. M., \& Slaik, E. (2002). Land and Property Taxation: A Review. A working paper of the Lincoln Institute of Land Policy.

Bird, R. M., \& Slaik, E. (2004). Land and Property Taxation in Guinea. An International Handbook of Land and Property Taxation. UK Edward Elgar. http://dx.doi.org/10.4337/9781845421434.00007

England, R. W., \& Ravichandran, M. (2010). Property Taxation and Density of Land Development: A Simple Model with numerical simulations. Eastern Economic Journal, 36, 229-238. 
http://dx.doi.org/10.10571 eej.2009.7

England, R. W., Zhao, M. Q., \& Huang, J. C. (2013). Impacts of Property Taxation on Residential Real Estate Development. Journal of Housing Economics, 22(1), 45-53. http://dx.doi/10.1016/j.jhe.2012.11.002

Ismail, T. (1986). Property Taxation as a Source of Revenue to the Local Government in Nigeria. A Paper Presented at a National Workshop on Property Taxation as a Source of Local Government Financing, Organised by the Ogun State Branch of The Nigerian Institution of Estate Surveyors and Valuers, Abeokuta, Ogun State, Nigeria.

Lewyn, M. (2013). The Side Effects of Property Taxes. Retrieved February 26, 2014, from $\mathrm{http} /:$ www.impactsofproperty taxes.com

Newel, T. A. (2001). Development and Neighbourhood Revitalization: The Effects of Residential Investment on Property Values in Durham, NC. The Michigan Journal of Business, 97-120.

Ogbuefi, J. U. (2004). Comparative Property Rating and Taxation. Institute for Development Studies, University of Nigeria, Enugu.

Olusegun, K. (2003). Fundamentals of Real Estate Taxation. Olusegun Kuye and Associates, Lagos, Nigeria.

Slack, E. (2010). The Property Tax in Theory and Practice. The Institute on Municipal Finance and Governance (IMFG). Working Paper 02, University of Toronto.

Song, Y., \& Yuez, Z. (2005). Property Tax and Urban Sprawl. Theory and Implications for US cities. A Lincoln Institute of Land Policy Working Paper WP05Y21.

Tsoodle, L. J., \& Turner, T. M. (2008). Property Taxes and Residential Rents. Journal of Real Estate Economics, 36(1), 63-80. http://dx.doi.org/10.1111/j.1540-6229.2008.00207.x

Yenger, J. (2005). Property Tax Capitalization. A Chapter in the E-book Housing and Community: The Theory of Urban Residential Structures. Academic Press.

Zodrow, G. R. (2001). The Property Tax as a Capital Tax: A room with Three Views. National Tax Journal, 54(1), 139-156.

\section{Copyrights}

Copyright for this article is retained by the author(s), with first publication rights granted to the journal.

This is an open-access article distributed under the terms and conditions of the Creative Commons Attribution license (http://creativecommons.org/licenses/by/3.0/). 